\title{
Investigation of the Effects of Stores' Tenant Mix and Internal and External Environmental Conditions on Customer Satisfaction from Shopping Centers in Iran
}

\author{
Maryam Abghari (Corresponding author) \\ Department of Business Management, Science and Research Branch \\ Islamic Azad University, Tehran, Iran \\ Tel: 98-21-4465-2374 Fax: 98-21-6641-1743 E-mail: maryam_abghari@yahoo.com \\ Kambiz Heidarzadeh Hanzaee \\ Department of Business Management, Science and Research Branch \\ Islamic Azad University, Tehran, Iran \\ E-mail: heidarzadeh@srbiau.ac.ir
}

Received: May 29, 2011 Accepted: July 12, $2011 \quad$ Published: November 1, 2011

doi:10.5539/ijms.v3n4p158 URL: http://dx.doi.org/10.5539/ijms.v3n4p158

\begin{abstract}
The research aims to determine the attractiveness of factors of Iranian shopping malls from the shopper's point of view. Researchers used a conceptual framework that proposes significant impact between store tenant mix, internal and external conditions from shopping centers, and different dimensions of attractiveness. Then they test the hypotheses using a survey of 385 consumers of two shopping centers of Iran, to identify shopping mall attractiveness. A structural equation model using a correlation matrix with maximum likelihood was estimated by LISREL 8.8. The results indicate that from the attractiveness factors, retail tenant mix and atmosphere were the most influential factors in shopping centers and retail tenant mix was strongly affected by product range and to some extent by merchandise value. Thus, management teams of shopping malls can increase their mall attractiveness by identifying optimal retail tenant mix and protect their establishments with appropriate atmosphere.
\end{abstract}

Keywords: Attractiveness dimensions, Consumers, Iran, Retailing, Shopping centers

\section{Introduction}

Today, malls play a major role in consumers' lifestyles (Terblanch, 1999). The mall has changed patterns of shopping as well as social and recreational activities since its first appearance in 1920s in the United States, and now malls are found almost everywhere in the world (Brown, 1992; Urban Land Institute, 1999). The retail industry in Iran has increased the last few years, too. Each person can easily notice a growing movement in establishing shopping malls.

The shopping center is an agglomeration of various retailers and commercial service providers within a well-planned, designed and managed building or group of buildings (ICSC, 2002; Urban Land Institution, 1999). Both consumers and retailers can gain benefits and/or realize synergetic effects from this phenomenon (Ghosh, 1986).

From a consumer's point of view, such a "bundling or agglomeration effect" delivers additional utilitarian and hedonic shopping values to customers (Oppewal and Holyoake, 2004; Babin et al., 1994). Such an enrichment of shopping experiences compared to those in single stores results from the provision of easy accessibility, parking facilities, orientation, a broad variety of shops, atmosphere and entertainment facilities (Kim, 2002). From a retail manager's view, such agglomerations have built up so-called "co-operation" between retailers (Brandenburger and Nalebauff, 1996). In fact, they cooperate by using the same infrastructure or environment such as parking and architecture, participate in marketing activities or benefit from the stream of consumers attracted by the whole agglomeration. 
With the growing number of malls, shoppers can select their destination, and they are more likely to patronize malls that are more attractive and have a wide variety of stores and merchandise that match their preferences. Therefore, it is essential for mall managers to know the extent to which their malls are attractive to their shoppers (Wong et al., 2001). On the other hand, insights into the interplay of determinants and moderating factors that affect malls' attractiveness can support managerial decision-making in the store location decisions and adjusting marketing strategies to increase the attractiveness of their malls (Reilly, 1931).

Therefore, the purpose of this research is to determine the attractiveness factors of shopping malls from the shoppers' perspective.

\section{Literature review}

Sets of retail outlets located in a nearby geographical area are referred to as retail agglomeration or retail cluster (Berman \& Evans, 2001; Ingene, 1984). Retail agglomerations are divided into two types: the form "created" includes shopping malls, galleries, strip centers or factory outlets, and the form "evolved" encompasses town centers, shopping strips, retail parks (Berman and Evans, 2009). In this research, we investigate the form created, shopping centers. The shopping center is an agglomeration of various retailers and commercial service provides within a well-planned, designed and managed building or groups of building (ICSC, 2002). Whether or not an agglomeration is a planned or unplanned form, it has some characteristics that influence consumer perception (Fin and Louviere, 1996). Attractiveness can be understood as a multi-faceted construct activated by at least three dimensions (Teller and Reutterer, 2008; Anselmsson, 2006): Satisfaction with the mall, retention proneness at the mall and patronage intention toward the mall. Each of these three determinants are strongly interlinked and underscore the importance for mall managers to meet their consumers' needs and wants in order to make them stay and to return in the future. Consequently, the attractiveness of a mall is related to the share of spending, share of time and share of choice of consumers relative to that of the competition.

Analogous to retail formats or individual stores' retail, agglomerations can be characterized by their marketing mix components, which are determined by managerially controllable decision parameters, such as accessibility, parking, product range, merchandise value, sales personnel, atmosphere, orientation and infrastructural facilities.

\subsection{Accessibility}

This factor accounts for the evaluation of the convenience regarding overcoming the distance between the points of origin and the agglomeration. It encompasses not only special and temporal dimensions concerning how easily and how quickly the destination can be reached, but also considers perceived obstacles on the way, such as traffic jams, travel frequencies of trains and buses, road work (Ingene, 1984). Thus, the following hypotheses are tested:

H1: Customer accessibility to shopping centers has a straight relationship with customer satisfaction from the shopping center.

H2: Customer accessibility to shopping centers has a straight relationship with retention proneness in shopping center.

H3: Customer accessibility to shopping centers has a straight relationship with patronage intention from the shopping center.

\subsection{Parking}

Today, cars can be seen as the most important means of transportation for consumers (Baker, 2002), thus the availability of free parking spaces and the type of parking facilities offered at the mall at the time of a shopping trip can also be regarded as a major factor enhancing shopping attractiveness (van der Waerden et al., 1998). Thus, the following hypotheses are tested:

H4: Parking has a straight relationship with customer satisfaction from the shopping center.

H5: Parking has a straight relationship with retention proneness in shopping center.

H6: Parking has a straight relationship with patronage intention from the shopping center.

\subsection{Retail tenant mix and non-retail tenant mix}

A good tenant mix includes a variety of compatible (or complementary) retail and service providers, an efficient space allocation (both size and number), and proper tenant placement, all of which encourage the interchange of customers and retail activities. The composition, the number, and type of retail and non-retail tenants - i.e. bars, eateries, entertainment facilities - within agglomerations represent the range of possibilities to satisfy consumers' wants and needs, as well as minimize the logistics of the shopping endeavors and influence shopping centers' 
attractiveness (Teller and Reutterer, 2008; Wakefield and Baker, 1998). Thus, the following hypotheses are tested:

H7: Retail tenant mix in shopping centers has a straight relationship with customer satisfaction from the shopping center.

H8: Retail tenant mix in shopping centers has a straight relationship with retention proneness in shopping center.

H9: Retail tenant mix in shopping centers has a straight relationship with patronage intention from the shopping center.

H10: Non-retail tenant mix in shopping centers has a straight relationship with customer satisfaction from the shopping center.

H11: Non-retail tenant mix in shopping centers has a straight relationship with retention proneness in shopping center.

H12: Non-retail tenant mix in shopping centers has a straight relationship with patronage intention from the shopping center.

\subsection{Product range, merchandise value and sales personnel}

The price-value ratio, the assortment of goods and services offered, and the type of sales personnel in an agglomeration can be seen as a consequence of the tenants located within it (Teller, 2008). The product range offered is evaluated in terms of the width and breadth of assortments of the retail stores, while the merchandise value is judged in terms of the overall price level and the number of price promotions available (Baker et al., 2002; Bearden, 1977), and sales personnel is evaluated in terms of friendliness, competency and supportiveness (Anselmson, 2006; Ruiz et al., 2004). These three factors also are regarded when judging a shopping center's attractiveness. Thus, the following hypotheses are tested:

H13: Merchandise value has a straight relationship with retail tenant mix in shopping centers.

H14: Product range has a straight relationship with retail tenant mix in shopping centers.

H15: Sales personnel have a straight relationship with retail tenant mix in shopping centers.

\subsection{Atmosphere}

Atmospheric stimuli including smell, music, decoration, or shopping mall layout and temperature are either actively or passively used by retail and mall managers (Michon et al, 2005). These stimuli have an effect on consumers' perception of the shopping center's attractiveness as well as their shopping behavior and provide enrichment and consequently an extension of the retention period of consumers. Thus, the following hypotheses are tested:

H16: Atmosphere of shopping centers has a straight relationship with customer satisfaction from the shopping center.

H17: Atmosphere of shopping centers has a straight relationship with retention proneness in shopping center.

H18: Atmosphere of shopping centers has a straight relationship with patronage intention from the shopping center.

\subsection{Orientation and infrastructural facilities}

Orientation accounts for the convenience relating to searching, locating, and accessing stores or other tenants within a mall. It is influenced by the arrangement of tenants as well as the ease of orientation within the retail location. Shopping center management tries to ease this (shopping) endeavour by providing a clear management of tenants within the premises and setting up directories that enable consumers to easily target and access the tenants they seek. Furthermore, the pace and number of obstacles that inhibit consumers' access to tenant mix need to be taken into consideration (Ingene 1984). In addition, infrastructure services within shopping centers such as the provision of public toilets, cash dispensers and recreational areas to meet the expectations and demand of consumers, support the fulfillment of the defined (shopping) tasks (Bellenger, 1977, Baker et al., 2002, Teller, 2008). Thus, the following hypotheses are tested:

H19: Orientation in shopping centers has a straight relationship with customer satisfaction from the shopping center.

H20: Orientation in shopping centers has a straight relationship with retention proneness in the shopping center.

H21: Orientation in shopping centers has a straight relationship with patronage intention from the shopping 
center.

H22: Infrastructural facilities in shopping centers have a straight relationship with customer satisfaction from the shopping center.

$\mathrm{H} 23$ : Infrastructural facilities in shopping centers have a straight relationship with retention proneness in the shopping center.

H24: Retail Infrastructural facilities in shopping centers have a straight relationship with patronage intention from the shopping center.

\subsection{Satisfaction, retention proneness, patronage intention}

In order to be successful, both retailers and shopping centers need to be attractive to their customers. Managers have to persuade consumers to come to their premises, make them stay and spend money, and convince them to come again. The perceived attractiveness of a shopping center varies along the following three dimensions: the satisfaction with a shopping center is considered to be an activated version of overall attractiveness, patronage intention measures the tendency toward revisiting the retail site, and retention proneness measures the propensity to stay and to spend time on site (Teller and Reutterer, 2008). Thus, the following hypotheses are tested:

H25: Customer satisfaction from shopping centers has a straight relationship with retention proneness in the shopping center.

H26: Customer satisfaction from shopping centers has a straight relationship with patronage intention from the shopping center.

\section{Conceptual model}

A conceptual model that proposes hypotheses in terms of effects between store tenant mix, internal and external conditions from shopping centers, and different dimensions of attractiveness has been used. This model was produced by Teller and Elms (2010): Therein the stimuli account for the characteristics of an agglomeration in terms of the variables that can be directly or indirectly influenced by the agglomeration management or any other internal groups, such as the tenants or local authorities. These characteristics are perceived as attributes by consumers and are then evaluated. The outcome of this evaluation process, and the integration of information and experiences with respect to an agglomeration, is that consumers will make an overall evaluation of the (overall) attractiveness of a format. This results in behavioral intentions and actual shopping behavior that can be measured in terms of the share of visits, share of spending, and share of time spent in an agglomeration compared to others (Teller and Elms, 2010, 31).

The conceptual model comprises 26 hypotheses or positive effects between attributes, i.e. exogenous factors of an agglomeration and the three dimensions of attractiveness, i.e. endogenous constructs (satisfaction, retention proneness, patronage intention).

\section{Insert Figure 1}

The generic attributes account for 10 factors: merchandise value, product range and personnel are the factors activating the retail offer of an agglomeration and are proposed to have a direct effect on attractiveness. All the other seven factors (accessibility, parking, retail tenant mix, non retail tenant mix, atmosphere, orientation and infrastructural facilities) are proposed to have a direct effect. Teller and Elms used this model in three competing agglomeration formats - a town center, a strip center and a regional shopping mall — but we used this model only in regional shopping malls.

\section{Method}

Based on the work of Teller and Reutterer (2008), an in vivo survey approach was applied. The standard questionnaire was translated from English to Farsi, and by using the back translation method, translated from Farsi to English. Consumers were given the questionnaire immediately after they had entered the shopping center. During a period of one month, 385 questionnaires were collected through a systematic sample method from consumers of two shopping centers. Of the respondents, 42 percent were males and 58 percent were females. The respondents can be considered as rather young: 56 percent of them were between 20 and 30 years old. Monthly income of 32 percent of respondents was $\$ 500$ to $\$ 1,000 \$$. The educational level was above average.

\section{Results and discussion}

A confirmatory factor analysis was conducted using LISREL8 to evaluate the factor structure, reliability, and discriminate validity. The X2 (df) was somewhat large, 1924.99, but the other fit indicators suggested that the fit of the measurement model was reasonable. The relative fit index was 0.92 ; the comparative fit index was 0.91 
and the root mean square residual 0.079. Cronbach's alpha scores are above or close to the minimum of 0.70 .

All paths are significant at, 0.05. H1 $(\mathrm{T}=1.15), \mathrm{H} 2(\mathrm{~T}=-0.28)$ and $\mathrm{H} 3(\mathrm{~T}=-0.83)$ were not supported. $\mathrm{H} 4(\mathrm{~T}=3.68)$ is supported, but H5 ( $\mathrm{T}=-0.39)$ and $\mathrm{H} 6(\mathrm{~T}=-0 / 21)$ were not supported. H7 ( $\mathrm{T}=6.42), \mathrm{H} 8(\mathrm{~T}=5.63)$ and $\mathrm{H} 9$ ( $\mathrm{T}=3.42)$ were supported. H10 $(\mathrm{T}=-0.93)$ and H12 $(\mathrm{T}=1.01)$ were not supported, but H11 $(\mathrm{T}=4)$ is supported. H13 $(\mathrm{T}=8.93)$ and H14 $(\mathrm{T}=7.45)$ were supported, but H15 $(\mathrm{T}=0.73)$ was not supported. H16 $(\mathrm{T}=-1 / 02), \mathrm{H} 17$ ( $\mathrm{T}=1.03), \mathrm{H} 18(\mathrm{~T}=0.87), \mathrm{H} 19(\mathrm{~T}=1.22), \mathrm{H} 20(\mathrm{~T}=-1.02)$ and $\mathrm{H} 21(\mathrm{~T}=-0.89)$ were not supported. $\mathrm{H} 22(\mathrm{~T}=4.12)$ and H23 $(\mathrm{T}=11.06)$ were supported, but H24 $(\mathrm{T}=-0.08)$ was not supported. H25 $(\mathrm{T}=3.14)$ and H26 $(\mathrm{T}=6 / 04)$ were supported.

According to the results, the impact of effects between the three endogenous factors was significant. The "retail tenant mix" was the most important influencing factor. The "atmosphere" influenced only satisfaction and retention proneness but not patronage intention. "Parking" influenced only satisfaction, and non-retail tenant mix only influenced retention proneness.

"Merchandise value" and "product range" impacted the retail tenant mix, but personnel didn't have any impact. "Accessibility," "orientation," and "infrastructural facilities" didn't impact on any of the endogenous factors.

\section{Conclusion and implication for shopping mall management}

Regarding the positive effect between satisfaction and retention proneness and patronage intention, we can say that any attractiveness factors directly effecting satisfaction also have an indirect effect on retention proneness and patronage intention.

Our finding indicates that, from the attractiveness factors, retail tenant mix and atmosphere were the most influential factors in shopping centers, which are consistent with Teller and Elms' (2010) findings.

Retail tenant mix was strongly affected by product range and to some extent by merchandise value. But, personnel didn't have any impact. Therefore, according to our findings, managers of shopping malls can increase their mall attractiveness by identifying optimal retail tenant mix and protect them with an appropriate atmosphere.

Atmosphere influenced satisfaction and retention proneness, and parking influenced satisfaction and patronage intention, but accessibility didn't influence any endogenous factors. According to Teller and Reutterer (2008), we can propose that the most important factor that attracts customers to shopping centers and can cover defects of parking, accessibility and infrastructural facilities, is retail tenant mix issues existing in shopping centers.

According to Teller (2008), one of the biggest differences between created agglomerations (such as shopping centers) and evolved agglomerations (such as shopping streets) is the management concept behind malls. A mall is a cluster of stores located in single building planned, designed and built for retailing and retail-related issues; they are managed as a single unit by an institutionalized center management (Levy and Weitz, 2006 ; ICSC, 2004). One aim of owners and the management of a mall is to increases the attractiveness, which should lead to opportunities for sales maximization for its tenants. Consequently, the price of rent mall tenants have to pay depends mostly on the attractiveness of the retail space and the sales volume they generate. But, unfortunately, in Iran's shopping center industry, unfortunately, investors aim to build shopping centers and sales immediately to profit from real estate investments and don't plan for appropriate retail tenant mix and central unit management. Therefore, we propose that investors pay attention more to this issue and consider that if a shopping center is attractive from the customer's point of view, it can drive higher real estate values attract more tenants.

\section{Limitations and future research}

The research suffers from some limitations: First, in this research we didn't consider different kinds of agglomerations, so the empirical evidence can only be applied to shopping centers and not different format of agglomerations. Second, no distinction was made between various groups of consumers based on their demographic, psychographic and behavioral characteristics.

This study does, however, offer several directions for future research: First, consideration of customer heterogeneity with respect to demographics or psychographics, as well as to shopping behavior, could further enrich our understanding of patronage behavior toward different retail agglomeration formats. Second, by comparing two or more agglomerations with the same survey, variety-seeking or shopping behaviors could be detected.

\section{References}

Anselmson, J. (2006). Sources of customer satisfaction with shopping malls: a comparative study of differ customer segments. Journal Review of Retail, Distribution \& Customer Research, 16 (1), 155-138. 
http://dx.doi.org/10.1080/09593960500453641

Babin, B.J., Darden, W.R., \& Griffin, M. (1994). Work and/or fun: measuring hedonic and utilitarian shopping. Journal of Consumer Research, 20 (4), 644-656. http://dx.doi.org/10.1086/209376

Bacon, R. W. (1995). Combined trips and the frequency of shopping. Journal of Retailing and Consumer Service, 2 (3), 175-183. http://dx.doi.org/10.1016/0969-6989(95)00034-8

Baker, J., Parasuraman, A., Grewal, D., \& Voss, G.B. (2002). The influence of multiple store environment cues on perceived merchandise value and patronage intentions. Journal of Marketing, 66 (2), 120-141. http://dx.doi.org/10.1509/jmkg.66.2.120.18470

Bearden, W.O. (1977). Determinant attributes of store patronage-downtown versus outlying shopping centers. Journal of Retailing, 53 (2), 15-22.

Bellenger, D.N. (1977). Shopping center patronage motives. Journal of Retailing, 53 (2), 29-38.

Berman, B., \& J. R. Evans (2007). Retail management. A strategic approach. Upper saddle River NJ, Pearson Prentice Hall.

Brandenburger, A., \& Malebuff, B. (1996). Co-opetition. New York: Doubleday.

Brown, S. (1991). Tenant placement and shopping centers: implications of an observation survey. Journal of Property Research, 8, 179-187.

Finn, A., \& Louviere, J.J. (1996). Shopping center image, consideration, and choice: another store contribution. Journal of Business Research, 35 (11), 936-50.

Ghosh, A. (1986). The value of a mall and other insights from a revised central place model. Journal of Retailing, $62(1), 79-97$.

ICSC (International Council of Shopping Centers) (2004). ICSC shopping center definitions. Basic configurations and type for the United States. [Online] Available: http://www.icsc.org/srch/lib/USD Definitions.pdf

Ingene, C.A. (1984). Productivity and functional shifting in spatial retailing: private and social perspectives. Journal of Retailing and Consumer Service, 60 (3), 15-26.

Kim,Y.K. (2002). Consumer Value: an application to mall and internet shopping. International Journal of Retail and Distribution Management, 30 (12), 595-602. http://dx.doi.org/10.1108/09590550210453075

Levy, M., \& Weitz, B.A. (2006). Retailing management. Boston:McGraw-Hill.

Michon, R., Chebat, J.C., \& Turley, L.W. (2005). Mall atmospherics: the interaction effects on shopping behavior. Journal of Business Research, 58 (5), 576-583. http://dx.doi.org/10.1016/j.jbusres.2003.07.004

Oppewal, H., \& Holyoake, B. (2004). Bundling and retail agglomeration effects on shopping behavior. Journal of Retailing and Consumer Service, 11 (2), 61-74. http://dx.doi.org/10.1016/S0969-6989(02)00079-6

Reilly, W. J. (1931). The law of retail gravition. New York.

Ruiz, J.P., Chebat, J.C., and Hansen, P. (2004). Another trip to the mal: a segmentation study of customers based on their activities. Journal of Retailing and Customer Service, 11 (6), 333-350. http://dx.doi.org/10.1016/j.jretconser.2003.12.002

Teller, C. (2008). Shopping streets versus shopping malls- determinants of agglomeration format attractiveness from the consumer's point of view. International Review of Retail, Distribution \& Consumer Research, 18(4), 381-403. http://dx.doi.org/10.1080/09593960802299452

Teller, C.,\& Reutterer, T. (2008). The evolving concept of retail attractiveness: what makes retail agglomerations attractive when customers shop at them?. Journal of Retailing and consumer service, 15 (3), 127-143. http://dx.doi.org/10.1016/j.jretconser.2007.03.003

Teller, C., \& Elms, J. (2010). Managing the attractiveness of evolved and created retail agglomeration formats. Marketing Intelligence \& Planning, 28 (1), 25-45. http://dx.doi.org/10.1108/02634501011014598

Terblanch, N.S. (1999). The perceived benefits derived from visits to a super regional shopping centre: an exploratory study. South Africa Journal of Business management, 30 (4), 141-146.

Urban Land Institute (1999). Shopping Center Development Handbook. in Spink, F. H. ed., Urban Land Institution. 
Van der Waerden, P. Borgers, A., \& Timmermans, H. (1998). The impact of the parking situation in shopping centers on store choice behavior. GeoJournal, 45 (4), 309-315. http://dx.doi.org/10.1016/j.jretconser.2007.03.003

Wakefield, K.L., \& Baker, J. (1998). Excitement at the mall: determinants and effects on shopping response. Journal of Retailing, 74 (4), 515-539. http://dx.doi.org/10.1016/S0022-4359(99)80106-7

Wong, G., L. Yu, \& L. Yuan (2001). SCATTR: an instrument for measuring shopping center attractiveness. International Journal of retail \& Distribution Management, 29 (2), 76-86. http://dx.doi.org/10.1108/09590550110381535

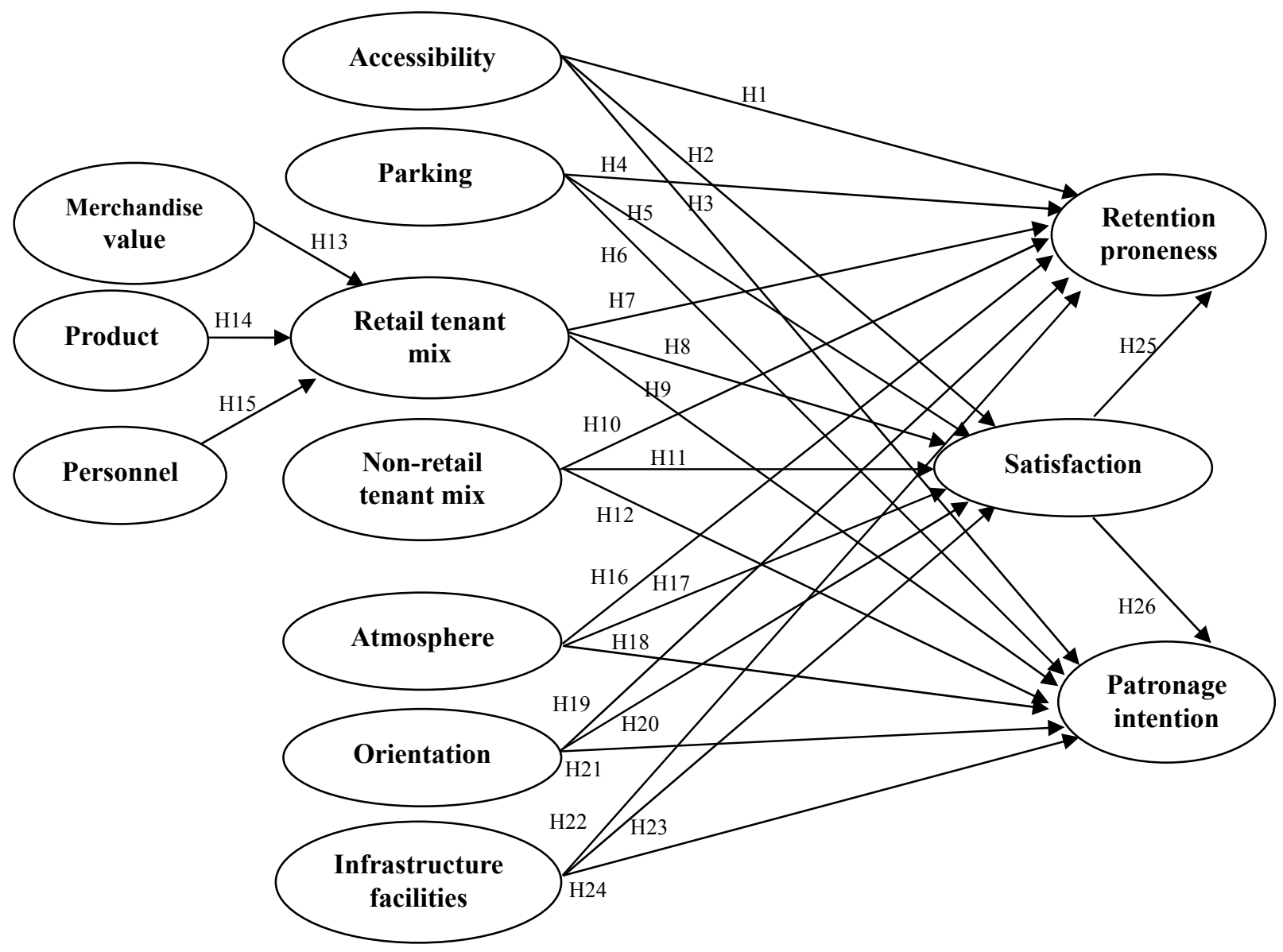

Figure 1. Conceptual model 